\title{
Phenotypic and haplotypic profiles of insecticide resistance in populations of Aedes aegypti larvae (Diptera: Culicidae) from central Lao PDR
}

Takaki Shimono ${ }^{1,2}$, Seiji Kanda ${ }^{1,2^{*}}$ (D), Pheophet Lamaningao ${ }^{1,2}$, Yuki Murakami ${ }^{1,2}$, Andrew Waleluma Darcy ${ }^{1}$, Nobuyuki Mishima', Somchit Inthavongsack ${ }^{3}$, Odai Soprasert ${ }^{4}$, Thonelakhanh Xaypangna ${ }^{4}$ and Toshimasa Nishiyama ${ }^{1}$

\begin{abstract}
Background: Aedes aegypti, which is widely distributed in the Lao People's Democratic Republic (PDR), is the primary vector of arboviral diseases. Chemical insecticides have been intensively used to eliminate mosquito-borne diseases, resulting in the development of insecticide resistance. However, little is known about the insecticide resistance of mosquito populations in Lao PDR and the mechanisms responsible for it, which have important implications for vector management programs. Here, we examined the phenotypic and haplotypic profiles of insecticide resistance in populations of Ae. aegypti larvae from central Lao PDR.

Methods: Ae. aegypti larvae were collected from four sites in Lao PDR, and their susceptibility to temephos, deltamethrin, permethrin, and Bacillus thuringiensis israelensis (Bti) was tested using larval bioassays. Synergistic tests were also conducted to evaluate the activity of insecticide-metabolizing enzymes in the larvae. Deltamethrinresistant and Deltamethrin-susceptible larvae were then genotyped for knockdown resistance ( $k d r)$ mutations to determine the associations between each genotype and resistance.

Results: Ae. aegypti larvae from central Lao PDR were considered to be "resistant" ( $<98 \%$ mortality) to organophosphates and pyrethroids. The bio-insecticide Bti remains effective against such larvae. The resistance mechanisms of Ae. aegypti larvae were found to vary among populations, especially for pyrethroid resistance. Kdr mutations were significantly associated with deltamethrin resistance in Ae. aegypti from the Xaythany population. In contrast, synergist assays with piperonyl butoxide suggested that cytochrome P450 monooxygenases played an important role in the resistance seen in the Khounkham and Thakhek populations.

(Continued on next page)
\end{abstract}

\footnotetext{
* Correspondence: kandas@hirakata.kmu.ac.jp

'Department of Hygiene and Public Health, Kansai Medical University,

Hirakata, Osaka, Japan

${ }^{2}$ Regenerative Research Center for Intractable Diseases, Kansai Medical

University, Hirakata, Osaka, Japan

Full list of author information is available at the end of the article
}

(c) The Author(s). 2021 Open Access This article is licensed under a Creative Commons Attribution 4.0 International License, which permits use, sharing, adaptation, distribution and reproduction in any medium or format, as long as you give appropriate credit to the original author(s) and the source, provide a link to the Creative Commons licence, and indicate if changes were made. The images or other third party material in this article are included in the article's Creative Commons licence, unless indicated otherwise in a credit line to the material. If material is not included in the article's Creative Commons licence and your intended use is not permitted by statutory regulation or exceeds the permitted use, you will need to obtain permission directly from the copyright holder. To view a copy of this licence, visit http://creativecommons.org/licenses/by/4.0/. 


\begin{abstract}
(Continued from previous page)
Conclusion: This study obtained information that will aid the design and implementation of insecticide-based vector management of Ae. aegypti in central Lao PDR. Ae. aegypti larvae from central Lao PDR were highly susceptible to Bti, while they were resistant to temephos at a diagnostic dose of $0.0286 \mathrm{mg} / \mathrm{L}$. Given the limited number of insecticides that are approved for vector control, it is important to alternate between temephos and other larvicides, such as Bti and pyriproxyfen. The differences in pyrethroid resistance mechanisms seen among the Ae. aegypti populations highlight the need to tailor vector-control strategies to each region to increase the success of dengue control in Lao PDR.
\end{abstract}

Keywords: Aedes aegypti, Dengue, Insecticide resistance, Bioassay, Synergist, kdr mutation, P450s, Lao PDR

\section{Background}

Aedes aegypti (Linnaeus), an aggressive and daytimebiting mosquito, is a species of significant medical and public health importance, due to its ability to transmit a multitude of arboviruses. It played an important role in recent dengue outbreaks worldwide. It is highly adapted to rural, semi-urban, and urban environments, where it can breed in a variety of artificial containers, and females feed on human blood. About 2.5 billion people in more than 100 tropical and subtropical countries where Ae. aegypti is found are at risk of contracting dengue [1]. Of this at-risk population, 1.8 billion live in countries in Asia or the Pacific region. Since no effective vaccines or therapeutics for arboviral diseases are available, vectorcontrol measures targeting Ae. aegypti have been used to minimize the incidence rates of such infections $[2,3]$.

Attempts to control Ae. aegypti have been based on reducing the number of larvae by eliminating larval habitats, e.g., by destroying or disposing of unused waterholding containers, such as jars, buckets, and old tires, and/or emptying them. Besides the mechanical elimination of mosquito habitats, the application of larvicidal treatments to larval habitats and outdoor and indoor adulticide-based spatial spraying operations carried out by house owners and/or local authorities have also been employed for many decades worldwide [2]. For both larvicidal and adulticidal purposes, organophosphates, such as malathion and temephos, and pyrethroids, such as deltamethrin, etofenprox, and permethrin, are commonly used [4]. However, the massive and widespread use of chemical insecticides has resulted in the development of insecticide resistance in dengue vectors, particularly Ae. aegypti, in many countries, which represents an operational challenge for vector-control programs $[2,5]$.

Ae. aegypti has evolved and developed various insecticide-resistance mechanisms, which mainly involve reductions in target-site sensitivity and enhanced metabolic detoxification. Metabolic detoxification is associated with upregulated expression of three major families of enzyme genes, i.e., the genes for cytochrome P450 monooxygenases (P450s), carboxylesterases (COEs), and glutathione Stransferases (GSTs). Another key resistance mechanism is target-site insensitivity caused by non-synonymous mutations in the gene for the voltage-gated sodium channel targeted by organochlorine and pyrethroid insecticides, which can arise through knockdown resistance $(k d r)$ [5-10]. Several $k d r$ mutations, such as V1016G and F1534C, have been identified in Ae. aegypti, and associations between these mutations and pyrethroid resistance have been confirmed [11-13].

Lao People's Democratic Republic (Lao PDR) is one of the countries in Southeast Asia affected by dengue, and all four dengue virus serotypes circulate in the country on a 2-5-year cyclical pattern [14-16]. The primary dengue vector, Ae. aegypti, is widely distributed throughout Lao PDR [17]. Compared with neighboring countries, there is a lack of studies on insecticide resistance in Ae. aegypti in Lao PDR, which could aid the establishment of effective and locally adapted vector-control systems.

In this study, we conducted bioassays, synergist assays, and genotyping of $k d r$ alleles to investigate the status of insecticide resistance and the associated molecular mechanisms in four field populations of Ae. aegypti larvae from suburban or rural areas along the Mekong River or its tributaries in central Lao PDR.

\section{Methods}

\section{Sampling}

The Aedes spp. larvae used in this study were collected between January and October 2019 in rural villages or suburban townships in four different locations in Bolikhamsai Province, Khammouane Province, or the capital Vientiane (Fig. 1). The larvae were collected from water storage containers, such as cement tanks and jars. Verbal permission was obtained from each householder to conduct entomological collections on their premises.

\section{Larval bioassay}

The following analytical-standard or technical-grade insecticides were used for the larval bioassays: deltamethrin (> 97.0\%; Tokyo Chemical Industry Co., Ltd., Tokyo, Japan), permethrin ( $\geq$ 90.0\%; Sigma-Aldrich, Inc., 


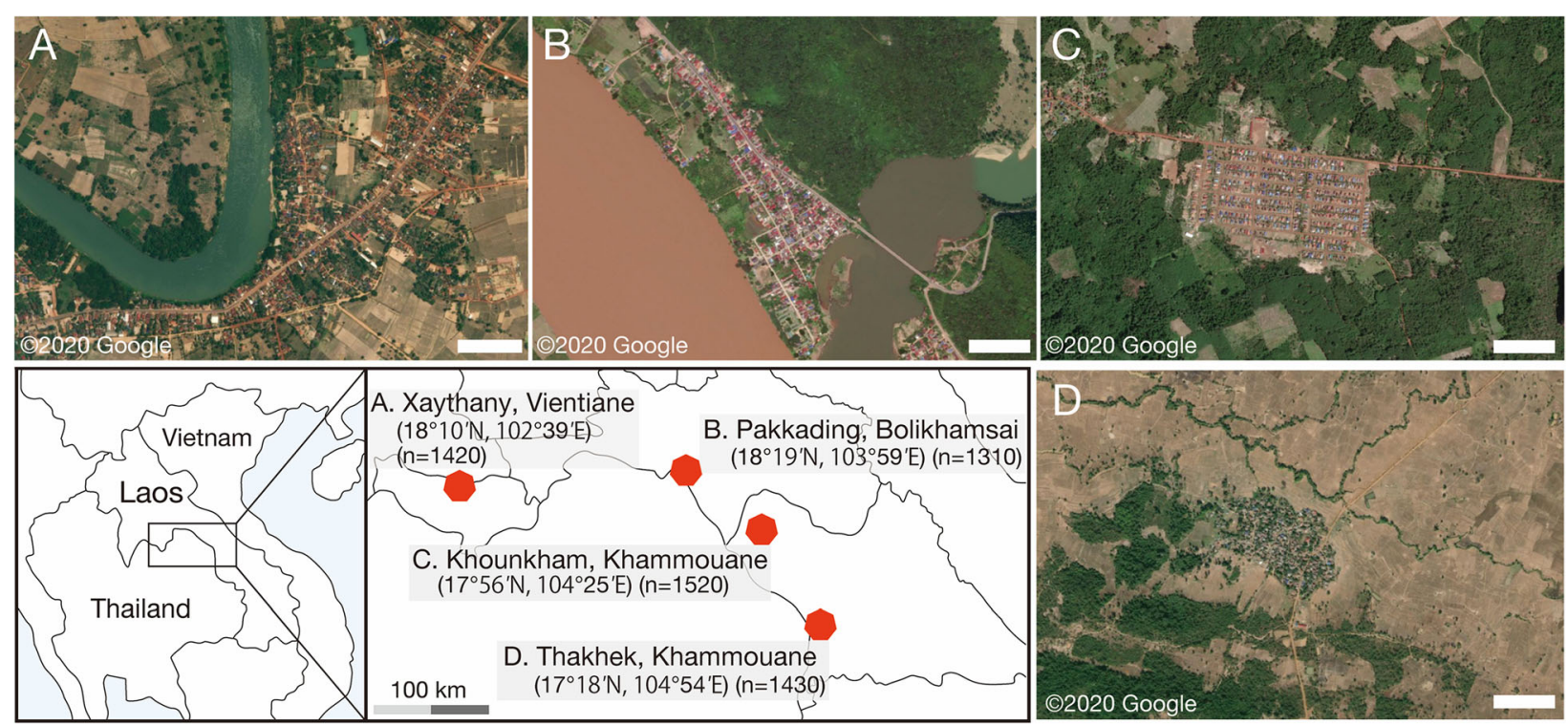

Fig. 1 Sampling sites and status of mosquito larvae at each site in central Lao PDR. a, b Suburban townships along the national highway in Xaythany, Vientiane, and Pakkading, Bolikhamsai. c A rural village surrounded by a forest in Khounkham, Khammouane. $\mathbf{d}$ A rural village surrounded by rice fields and a forest in Thakhek, Khammouane; n: number of Aedes spp. larvae collected from each population; scale bars A-D $250 \mathrm{~m}$

MO, USA), temephos ( $\geq 95.0 \%$; Sigma-Aldrich, Inc.), and Bacillus thuringiensis israelensis (Bti) (VectoBac WG, 3000 international toxic units/mg, strain H-14) (Sumitomo Chemical Co., Ltd., Tokyo, Japan). The stock solutions of pyrethroids and temephos were prepared in dimethyl sulfoxide (DMSO) (Fujifilm Corp., Tokyo, Japan). The DMSO concentration of each final solution was $<0.1 \%$, which did not affect the survival rate of Aedes spp. in the larval bioassays (data not shown). The stock solution of Bti was prepared in distilled water.

The diagnostic dose of an insecticide is a dose that is two-fold higher than the lethal concentration and kills 99\% of an insecticide-susceptible reference strain, such as Bora-Bora or the US Department of Agriculture strain, in World Health Organization (WHO) larval bioassays. However, the diagnostic doses of most of the insecticides used against Ae. aegypti have not yet been determined. Furthermore, unfortunately no reference strains were available for this study, and hence, the diagnostic doses of the examined insecticides could not be established. Therefore, the larval bioassays performed in the present study involved diagnostic doses of deltamethrin $(0.003 \mathrm{mg} / \mathrm{L})$, permethrin $(0.008 \mathrm{mg} / \mathrm{L})$, temephos $(0.0286 \mathrm{mg} / \mathrm{L})$, and $B t i(1.1406 \mathrm{mg} / \mathrm{L})$ that were established using the Bora-Bora strain in previous studies $[18,19]$.

Bioassays were carried out using wild mosquito larvae obtained from the sampling site on the day of collection. Each bioassay was conducted using a disposable, transparent, $180-\mathrm{mL}$ plastic cup, containing $99 \mathrm{~mL}$ of distilled water, and $1 \mathrm{~mL}$ of insecticide solution at the desired concentration. Twenty-five to 30 third- to fourth-instar larvae were randomly selected and transferred to the cup for 10-15 min before the addition of the insecticide solution. Three to 6 replications were carried out for each insecticide for all four field strains. Mortality was assessed after $24 \mathrm{~h}$ of exposure at room temperature. Larvae that sank to the bottom of the cup and could not swim or float, or were paralyzed were judged to be knockeddown larvae.

To evaluate the effectiveness of insecticide detoxification by the mosquitoes, three synergists, ethacrynic acid (EA, $\geq$ 95.0\%; Sigma-Aldrich, Inc.), piperonyl butoxide (PBO, 98.0\%; Fujifilm Corp.), and triphenyl phosphate (TPP, > 99.0\%; Tokyo Chemical Industry Co., Ltd.), were used to conduct synergist tests. Sublethal doses of EA $(0.1 \mathrm{mg} / \mathrm{L})$, PBO $(5 \mathrm{mg} / \mathrm{L})$, and TPP $(1 \mathrm{mg} / \mathrm{L})$, which were determined in previous studies, were used in these tests $[18,19]$. The larval synergist tests were conducted similarly to the larval bioassays, although they involved an additional step, in which the synergist and insecticide was mixed at a 1:1 ratio before the larvae were exposed to them. Each of the synergists was combined with each of the insecticides, except Bti.

To investigate the associations between deltamethrin resistance and $k d r$ mutations, after the bioassays each larva was examined under a dissecting microscope to identify Ae. aegypti, according to the characteristics described in a previous study [20], and then was stored in a $1.5-\mathrm{mL}$ plastic tube containing ethanol solution until it was used for the subsequent genetic analysis. 


\section{Knockdown resistance $(k d r)$ genotyping}

Direct DNA sequencing was conducted to detect the L982W, S989P, I1011M/V, V1016G, T1520I, and F1534C point mutations in Ae. aegypti. Each population contained a maximum of 25 live and 25 dead larvae, which were randomly selected from among those used for the deltamethrin bioassay, and the total number of extracts used for the $k d r$ genotyping was 163 .

Genomic DNA was extracted from individual mosquitoes using Isogenome (Nippon Gene Co., Ltd., Tokyo, Japan), according to the manufacturer's instructions, in a final volume of $30 \mu \mathrm{L}$ of distilled water. The polymerase chain reaction (PCR) was performed using TaKaRa Ex Taq, hot start version (Takara Bio, Shiga, Japan), under the following conditions: initial denaturation was conducted at $94{ }^{\circ} \mathrm{C}$ for $2 \mathrm{~min}$; followed by 5 cycles of $98{ }^{\circ} \mathrm{C}$ for $10 \mathrm{~s}, 60^{\circ} \mathrm{C}$ for $30 \mathrm{~s}$, and $72{ }^{\circ} \mathrm{C}$ for $1 \mathrm{~min} ; 30$ cycles of $98{ }^{\circ} \mathrm{C}$ for $10 \mathrm{~s}, 58{ }^{\circ} \mathrm{C}$ for $30 \mathrm{~s}$, and $72{ }^{\circ} \mathrm{C}$ for $1 \mathrm{~min}$; and a final extension step of $72{ }^{\circ} \mathrm{C}$ for $5 \mathrm{~min}$. The PCR products were purified as described above, and then the DNA sequencing was carried out using the BigDye Terminator, version 3.1, cycle sequencing kit (ThermoFisher Scientific, Inc., MA, USA), according to the manufacturer's instructions. The amplification and partial sequencing of the target regions were conducted using the primers shown in Table 1 . Direct DNA sequencing was performed using the $3130 \times 1$ analyzer (ThermoFisher Scientific, Inc.). The electropherograms of the replacement amino acids found in the target regions were analyzed with the MEGA 7.0 software [22].

\section{Phenotype-haplotype associations}

To assess the roles of the S989P, V1016G, T1520I, and F1534C mutations in deltamethrin resistance, we conducted a phenotype-haplotype analysis by comparing the distributions of these $k d r$ mutations between dead and alive mosquito larvae that had been exposed to deltamethrin.

\section{Statistical analyses}

Statistical analyses were performed using GraphPad Prism, version 8.10 (San Diego, CA, USA, www. graphpad.com), and EZR, which is based on $R$ and $R$ commander [23]. Fisher's exact test with Holm's correction for multiple comparisons was used to compare the resistant allele frequency of S989P, V1016G, and F1534C among the Ae. aegypti larvae in the four field populations. One-way analysis of variance (ANOVA) followed by Tukey's multiple comparisons test was used to compare the larval mortality rates produced by temephos, deltamethrin, and permethrin in each population. Oneway ANOVA followed by Dunnett's multiple comparisons test was used to compare larval mortality rates between the groups treated with insecticides and those treated with combinations of insecticides and synergists. Odds ratios (ORs) and 95\% confidence intervals (95\% $\mathrm{CI})$ were estimated using Fisher's exact test to assess the associations between $k d r$ mutations and resistant phenotypes.

\section{Results}

\section{Bioassays}

A total of 5680 Aedes spp. larvae were collected from four populations (Fig. 1). In the bioassays, we identified Aedes spp. larvae based on their morphological features. Ae. aegypti was the predominant larval species in the Xaythany, Khounkham, and Thakhek populations. In contrast, Ae. albopictus accounted for a large proportion of the Pakkading population (data not shown). Accordingly, the samples collected from Pakkading were excluded from the statistical analyses of the larval bioassays due to the insufficient Ae. aegypti sample size.

The mortality rates of the Ae. aegypti larvae treated with temephos, deltamethrin, or permethrin in the three populations were $<90 \%$ at the diagnostic doses employed in the bioassay. According to the WHO standards, an Ae. aegypti population is classified as "resistant" if its morality rate is $<90 \%$, as "suspected" if its mortality rate ranges from $90 \%$ to $98 \%$, and as "susceptible" if its mortality rate is $>98 \%$ [24]. The results of the bioassays indicated that the Ae. aegypti from the three sites were "insecticide-resistant." On the other hand, the bio-insecticide Bti resulted in 100\% mortality in all populations (Fig. 2, Table S1).

When the larvae from the three sites were treated with temephos, their mortality rates ranged from 64.0 to

Table 1 The primers used for the $k d r$ genotyping

\begin{tabular}{lll}
\hline Amplified region & Primer name & Primer sequence (5'-3') \\
\hline L982W, S989P, I1011MN, and V1016G & AaS CF1 (PCR) & AGACAATGTGGATCGCTTCC \\
& AaS CR4 (PCR and DNA sequencing) & GGACGCAATCTGGCTTGTTA \\
T1520l and F1534C & AaS CF3 (DNA sequencing) & GTGGAACTTCACCGACTTCA \\
& AaS CF7 (PCR and DNA sequencing) & GAGAACTCGCCGATG AACTT \\
& AaS CR7 (DNA sequencing) & GACGACGAAATCGAACAGGT \\
& AaS CR8 (PCR) & TAGCTTCAGCGGCTT CTTC \\
\hline
\end{tabular}

The primer sequences were obtained from a study by Kawada et al. 2016 [21] 
$89.7 \%$. In contrast, the mortality rates produced by deltamethrin and permethrin were significantly lower than those produced by temephos in all of the Ae. aegypti populations (Fig. 2, Table S1).

Significant differences in the temephos- and pyrethroid-related mortality rates were observed among the Ae. aegypti populations. The mortality rates produced by temephos and deltamethrin in the Ae. aegypti population in Thakhek were significantly higher than those seen in the Ae. aegypti population in Khounkham
( $p<0.05$ and $p<0.01$, respectively). On the other hand, the Ae. aegypti mortality rate produced by permethrin was higher in Xaythany than in Khounkham and Thakhek ( $p<0.01$ and $p<0.05$, respectively) (Table S1).

\section{Synergist tests}

Synergist tests were performed to investigate the role of insecticide detoxification in insecticide resistance in $A e$. aegypti. The treatment of Ae. aegypti larvae with any of the three synergists alone did not affect the survival rate

\section{Xaythany}

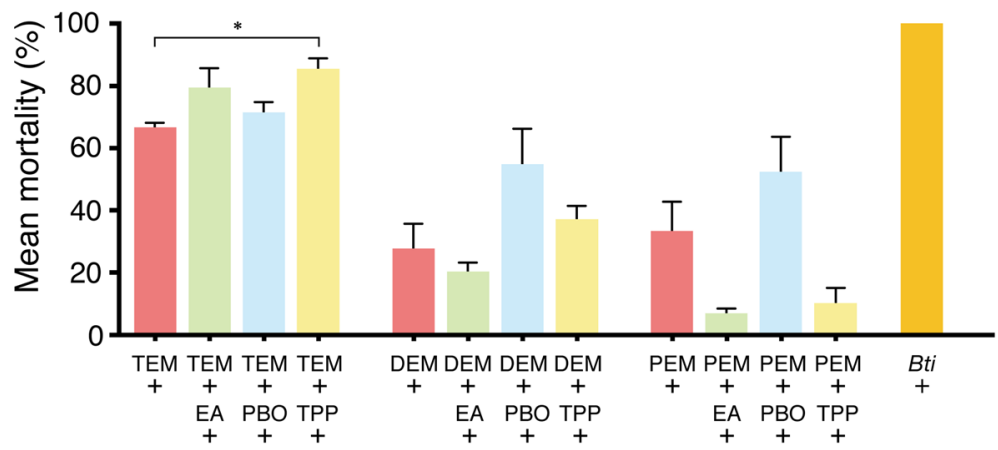

Khounkham

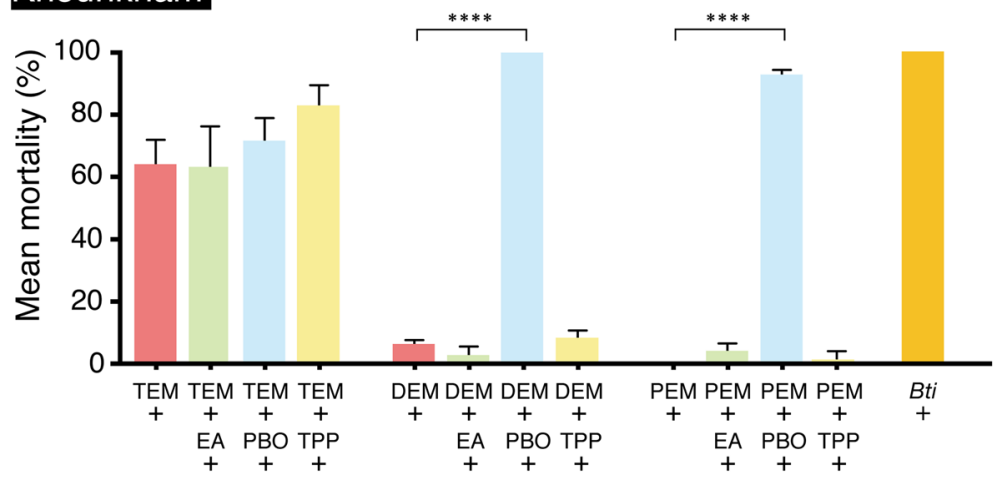

Thakhek

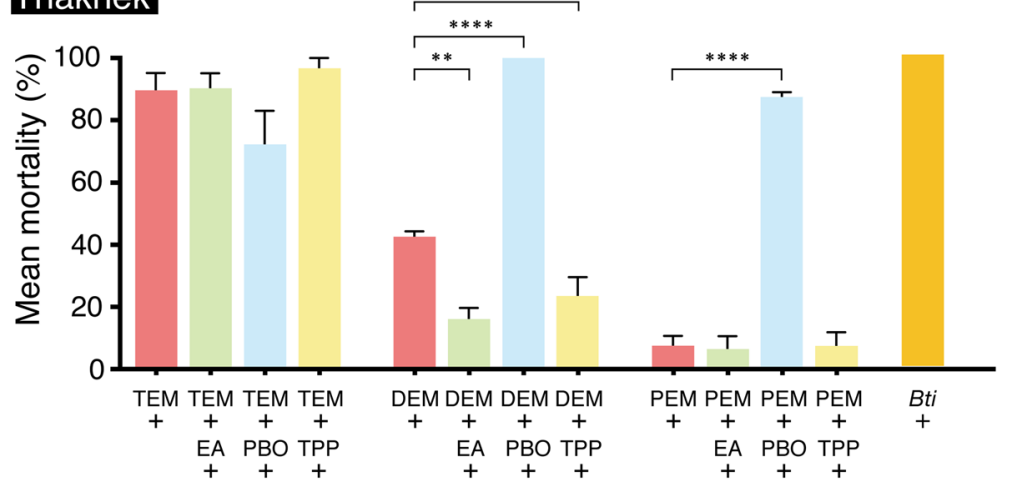

Fig. 2 Comparison of the mortality rates of Ae. aegypti larvae treated with different insecticides and synergists. Ordinary one-way ANOVA and Dunnett's multiple comparisons test, with a single pooled variance, were used for the analyses. Significant differences in mortality rates between the groups treated with an insecticide alone and those treated with an insecticide plus a synergist is indicated by asterisks. ${ }^{*} p<0.05,{ }^{*} p<0.01$, ${ }^{* * * *} p<0.0001$; TEM: temephos, DEM: deltamethrin, PEM: permethrin 
of the larvae (Table S1). The synergist tests showed that the mortality rate produced by temephos plus TPP was significantly higher than that produced by temephos alone in the Ae. aegypti population from Xaythany, while none of the other three synergists (EA, TPP, or PBO) increased the temephos-induced mortality rate of the Ae. aegypti larvae from any of the three locations (Fig. 2, Table S1).

PBO treatment led to marked increases in the $A e$. aegypti mortality rates produced by deltamethrin and permethrin in Khounkham and Thakhek. On the other hand, the mortality rates produced by these insecticides were slightly, but not significantly, increased by PBO in Xaythany. When EA or TPP was used in conjunction with deltamethrin or permethrin, no significant changes in the mortality rate were found in any of the Ae. aegypti populations (Fig. 2, Table S1).

\section{Knockdown resistance (kdr) genotyping}

Genotyping of the sodium channel gene of Ae. aegypti to detect the L982W, S989P, I1011M/V, V1016G, T1520I, and F1534C mutations was carried out on individuals (163 in total), which were collected from four different locations, including Pakkading, and subjected to a bioassay.

No L982W or I1011M/V amino acid mutations were observed in any of the assayed individuals, while S989P,
V1016G, T1520I, and F1534C amino acid mutations were found in some individuals (accession numbers LC605641 to LC605645).

Focusing on the presence and frequency of the S989P, V1016G, T1520I, and F1534C mutations in the Ae. aegypti at each site, the F1534C mutation was found in all of the examined populations. The allelic frequency of $1534 \mathrm{C}$ was relatively high, ranging from 55.0 to $92.0 \%$. It was particularly high in the populations from Khounkham (91.4\%) and Thakhek (92.0\%). The T1520I mutation was detected in all of the examined populations, and the allelic frequency of this mutation ranged from $1.0 \%$ to $8.6 \%$. The $5989 \mathrm{P}$ and V1016G mutations were always found together. The allelic frequencies of $989 \mathrm{P}$ and $1016 \mathrm{G}$ were $32.0 \%$ and $31.0 \%$, respectively, in the population from Xaythany, and $26.5 \%$ in the population from Pakkading, while it was $8.6 \%$; i.e., a quarter of that seen in the population from Xaythany, in the population from Khounkham, and no such mutations were observed in the population from Thakhek (Fig. 3).

Significant differences in the frequencies of the 989P and 1016G alleles were found among the populations, except between the Xaythany and Pakkading populations $(p<0.05)$, and significant differences in the frequency of the $1534 \mathrm{C}$ allele were found among the populations, except between the Xaythany and Pakkading populations, and the Khounkham and Thakhek populations $(p<$ 0.05). No significant differences in the frequency of the

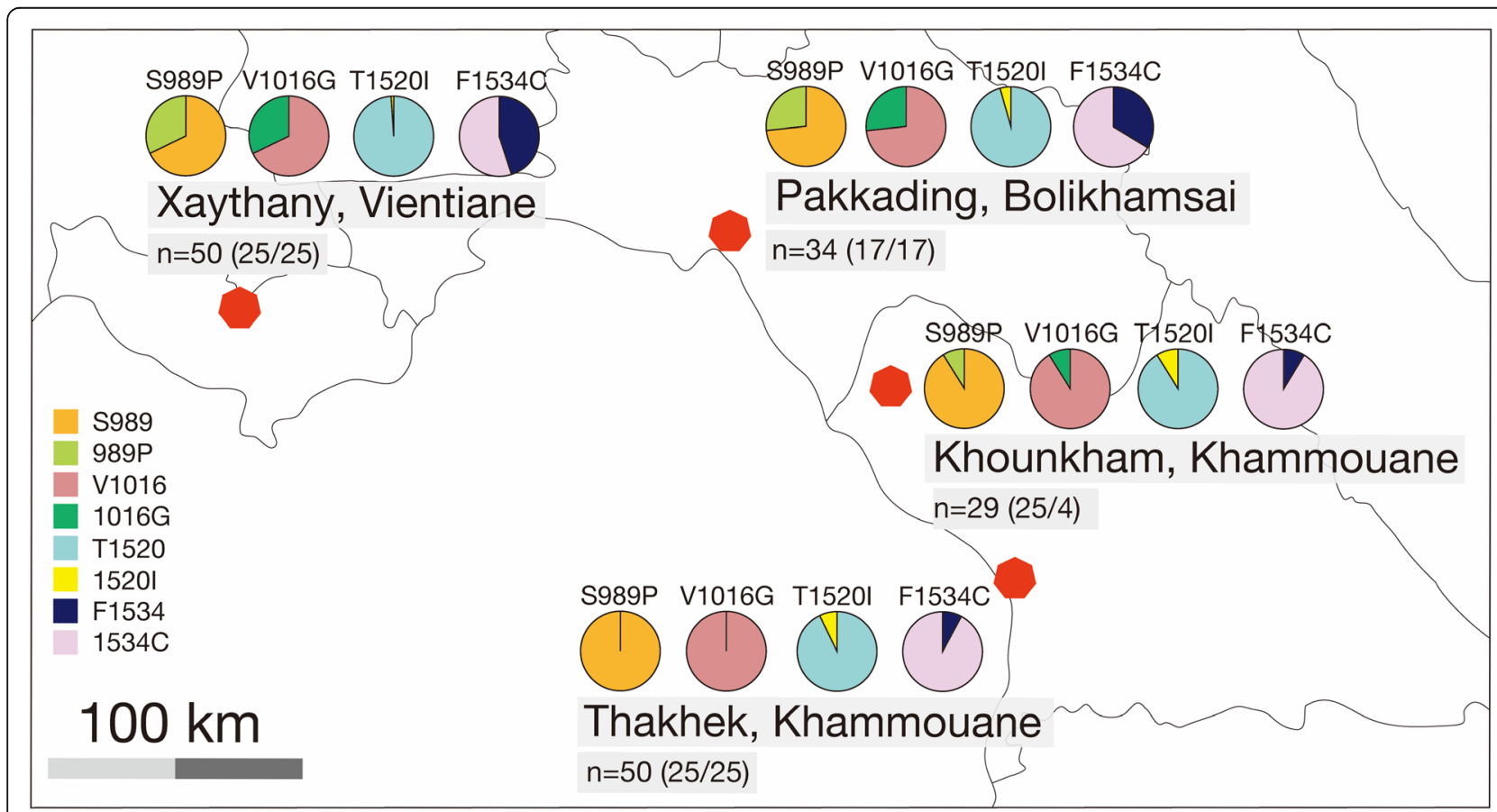

Fig. 3 Distribution of $k d r$ alleles among field populations of Ae. aegypti that were subjected to bioassays. In the Khounkham population, since only four mosquitoes that were susceptible to deltamethrin were available for the bioassay, only four susceptible mosquitoes were subjected to kdr genotyping. n: number of samples analyzed (alive/dead) 
1520I allele were found among the populations $(p>$ 0.05) (Table S2).

We identified thirteen genotypes and five haplotypes in the current study (Table 2, Table S3). In addition to detecting a single $k d r$ mutation, namely F1534C (S-V-T$\mathrm{C}$ haplotype), three co-occurring $k d r$ mutations, V1016G + S989P (P-G-T-F haplotype), T1520I+F1534C (S-V-I-C haplotype), and V1016G + F1534C+S989P (P-G-T-C haplotype), were also found. The frequencies of these multiple-mutant haplotypes (P-G-T-F, S-V-I-C, and PG-T-C) in the Ae. aegypti larvae from the four populations ranged from 0 to $20.0 \%, 2.0$ to $13.8 \%$, and 0 to $29.4 \%$, respectively. No single S989P, V1016G, or T1520I $k d r$ mutations were detected.

\section{Associations between $k d r$ mutations and resistant phenotypes}

The genotyping of the $k d r$ mutations was conducted on a group of living individuals and a group of dead individuals (a maximum of 25 individuals in each group) for each site. These individuals were subjected to a bioassay to verify whether a relationship existed between resistance to deltamethrin and particular results revealed that the S-V-T-C haplotype (a single $1534 \mathrm{C}$ mutant) was not related to resistance to deltamethrin in any of the populations or in the whole study population $(\mathrm{OR}\langle 1.0, p\rangle$ 0.05; Table 3). On the other hand, the P-G-T-F haplotype (V1016G + S989P) was significantly associated with resistance to deltamethrin in the population from Xaythany and in the whole study population (OR $>1.0$, $p<0.01$ ) (Table 4). In addition to the P-G-T-F haplotype, the P-G-T-C haplotype (V1016G + F1534C+ S989P) exhibited OR for resistance to deltamethrin of $9.33(p=0.049)$ in the population from Xaythany and $5.90(p=0.002)$ in the whole study population, which confirmed that these haplotypes are significantly related to resistance to deltamethrin (Table 5).

\section{Discussion}

Resistance to temephos and Bti

In the present study, the diagnostic doses of the insecticides could not be determined using a susceptible

Table 2 Frequency of thirteen kdr genotypes in Ae. aegypti larvae collected from four populations

\begin{tabular}{|c|c|c|c|c|c|c|c|c|c|c|c|c|c|}
\hline \multirow[t]{4}{*}{ Haplotype } & \multirow[t]{4}{*}{ Genotype } & \multirow{2}{*}{\multicolumn{3}{|c|}{$\begin{array}{l}\text { Xaythany } \\
\text { No. of samples analyzed }\end{array}$}} & \multirow{2}{*}{\multicolumn{3}{|c|}{$\begin{array}{l}\text { Pakkading } \\
\text { No. of samples analyzed }\end{array}$}} & \multirow{2}{*}{\multicolumn{3}{|c|}{$\begin{array}{l}\text { Khounkham } \\
\text { No. of samples analyzed }\end{array}$}} & \multirow{2}{*}{\multicolumn{3}{|c|}{$\begin{array}{l}\text { Thakhek } \\
\text { No. of samples analyzed }\end{array}$}} \\
\hline & & & & & & & & & & & & & \\
\hline & & \multirow{2}{*}{$\begin{array}{l}\text { Alive } \\
25\end{array}$} & \multirow{2}{*}{$\begin{array}{l}\text { Dead } \\
25\end{array}$} & \multirow{2}{*}{$\begin{array}{l}\text { Total } \\
50\end{array}$} & \multirow{2}{*}{$\begin{array}{l}\text { Alive } \\
17\end{array}$} & \multirow{2}{*}{$\begin{array}{l}\text { Dead } \\
17\end{array}$} & \multirow{2}{*}{$\begin{array}{l}\text { Total } \\
34\end{array}$} & \multirow{2}{*}{$\begin{array}{l}\text { Alive } \\
25\end{array}$} & \multirow{2}{*}{$\begin{array}{l}\text { Dead } \\
4\end{array}$} & \multirow{2}{*}{$\begin{array}{l}\text { Total } \\
29\end{array}$} & \multirow{2}{*}{$\begin{array}{l}\text { Alive } \\
25\end{array}$} & \multirow{2}{*}{$\begin{array}{l}\text { Dead } \\
25\end{array}$} & \multirow{2}{*}{$\begin{array}{l}\text { Total } \\
50\end{array}$} \\
\hline & & & & & & & & & & & & & \\
\hline$-\mathrm{V}-\mathrm{T}-\mathrm{F}$ & $\begin{array}{l}\mathrm{S} / \mathrm{S}+\mathrm{V} N+\mathrm{T} / \mathrm{T} \\
+\mathrm{F} / \mathrm{F}\end{array}$ & $\begin{array}{l}0.00(0 / \\
25)\end{array}$ & $\begin{array}{l}0.04(1 / \\
25)\end{array}$ & $\begin{array}{l}0.02(1 / \\
50)\end{array}$ & $\begin{array}{l}0.00(0 / \\
17)\end{array}$ & $\begin{array}{l}0.12(2 / \\
17)\end{array}$ & $\begin{array}{l}0.06(2 / \\
34)\end{array}$ & $\begin{array}{l}0.00(0 / \\
25)\end{array}$ & $\begin{array}{l}0.00 \\
(0 / 4)\end{array}$ & $\begin{array}{l}0.00(0 / \\
29)\end{array}$ & $\begin{array}{l}0.04(1 / \\
25)\end{array}$ & $\begin{array}{l}0.08(2 / \\
25)\end{array}$ & $\begin{array}{l}0.06(3 / \\
50)\end{array}$ \\
\hline \multirow[t]{2}{*}{ S-V-T-CE } & $\begin{array}{l}\mathrm{S} / \mathrm{S}+\mathrm{V} / \mathrm{N}+\mathrm{T} / \mathrm{T} \\
+\mathrm{F} / \underline{\mathrm{C}}\end{array}$ & $\begin{array}{l}0.20(5 / \\
25)\end{array}$ & $\begin{array}{l}0.44 \\
(11 / 25)\end{array}$ & $\begin{array}{l}0.32 \\
(16 / 50)\end{array}$ & $\begin{array}{l}0.12(2 / \\
17)\end{array}$ & $\begin{array}{l}0.24(4 / \\
17)\end{array}$ & $\begin{array}{l}0.18(6 / \\
34)\end{array}$ & $\begin{array}{l}0.08(2 / \\
25)\end{array}$ & $\begin{array}{l}0.00 \\
(0 / 4)\end{array}$ & $\begin{array}{l}0.07(2 / \\
29)\end{array}$ & $\begin{array}{l}0.00(0 / \\
25)\end{array}$ & $\begin{array}{l}0.12(3 / \\
25)\end{array}$ & $\begin{array}{l}0.06(3 / \\
50)\end{array}$ \\
\hline & $\begin{array}{l}\mathrm{S} / \mathrm{S}+\mathrm{V} N+\mathrm{T} / \mathrm{T} \\
+\underline{\mathrm{C}} \underline{\mathrm{C}}\end{array}$ & $\begin{array}{l}0.16(4 / \\
25)\end{array}$ & $\begin{array}{l}0.40 \\
(10 / 25)\end{array}$ & $\begin{array}{l}0.28 \\
(14 / 50)\end{array}$ & $\begin{array}{l}0.35(6 / \\
17)\end{array}$ & $\begin{array}{l}0.29(5 / \\
17)\end{array}$ & $\begin{array}{l}0.32 \\
(11 / 34)\end{array}$ & $\begin{array}{l}0.64 \\
(16 / 25)\end{array}$ & $\begin{array}{l}0.75 \\
(3 / 4)\end{array}$ & $\begin{array}{l}0.66 \\
(19 / 29)\end{array}$ & $\begin{array}{l}0.92 \\
(23 / 25)\end{array}$ & $\begin{array}{l}0.64 \\
(16 / 25)\end{array}$ & $\begin{array}{l}0.78 \\
(39 / 50)\end{array}$ \\
\hline \multirow[t]{3}{*}{ S-V-I-C } & $\begin{array}{l}\mathrm{S} / \mathrm{S}+\mathrm{V} N+\mathrm{T} / \mathrm{I} \\
+\mathrm{F} / \underline{\mathrm{C}}\end{array}$ & $\begin{array}{l}0.00(0 / \\
25)\end{array}$ & $\begin{array}{l}0.00(0 / \\
25)\end{array}$ & $\begin{array}{l}0.00(0 / \\
50)\end{array}$ & $\begin{array}{l}0.00(0 / \\
17)\end{array}$ & $\begin{array}{l}0.06(1 / \\
17)\end{array}$ & $\begin{array}{l}0.03(1 / \\
34)\end{array}$ & $\begin{array}{l}0.00(0 / \\
25)\end{array}$ & $\begin{array}{l}0.00 \\
(0 / 4)\end{array}$ & $\begin{array}{l}0.00(0 / \\
29)\end{array}$ & $\begin{array}{l}0.00(0 / \\
25)\end{array}$ & $\begin{array}{l}0.00(0 / \\
25)\end{array}$ & $\begin{array}{l}0.00(0 / \\
50)\end{array}$ \\
\hline & $\begin{array}{l}\mathrm{S} / \mathrm{S}+\mathrm{V} / \mathrm{N}+\mathrm{T} / \mathrm{I} \\
+\underline{C} \underline{C}\end{array}$ & $\begin{array}{l}0.00(0 / \\
25)\end{array}$ & $\begin{array}{l}0.04(1 / \\
25)\end{array}$ & $\begin{array}{l}0.02(1 / \\
50)\end{array}$ & $\begin{array}{l}0.00(0 / \\
17)\end{array}$ & $\begin{array}{l}0.12(2 / \\
17)\end{array}$ & $\begin{array}{l}0.06(2 / \\
34)\end{array}$ & $\begin{array}{l}0.12(3 / \\
25)\end{array}$ & $\begin{array}{l}0.25 \\
(1 / 4)\end{array}$ & $\begin{array}{l}0.14(4 / \\
29)\end{array}$ & $\begin{array}{l}0.04(1 / \\
25)\end{array}$ & $\begin{array}{l}0.08(2 / \\
25)\end{array}$ & $\begin{array}{l}0.06(3 / \\
50)\end{array}$ \\
\hline & $\begin{array}{l}\mathrm{S} / \mathrm{S}+\mathrm{V} / \mathrm{N}+\underline{\mathrm{I}} / \mathrm{I}+ \\
\underline{\mathrm{C}} \underline{\mathrm{C}}\end{array}$ & $\begin{array}{l}0.00(0 / \\
25)\end{array}$ & $\begin{array}{l}0.00(0 / \\
25)\end{array}$ & $\begin{array}{l}0.00(0 / \\
50)\end{array}$ & $\begin{array}{l}0.00(0 / \\
17)\end{array}$ & $\begin{array}{l}0.00(0 / \\
17)\end{array}$ & $\begin{array}{l}0.00(0 / \\
17)\end{array}$ & $\begin{array}{l}0.00(0 / \\
25)\end{array}$ & $\begin{array}{l}0.00 \\
(0 / 4)\end{array}$ & $\begin{array}{l}0.00(0 / \\
29)\end{array}$ & $\begin{array}{l}0.00(0 / \\
25)\end{array}$ & $\begin{array}{l}0.08(2 / \\
25)\end{array}$ & $\begin{array}{l}0.04(2 / \\
50)\end{array}$ \\
\hline \multirow[t]{2}{*}{$\underline{P}-\underline{G}-T-F$} & $\begin{array}{l}\frac{P}{+} \bar{P}+V / F \\
F / G\end{array}$ & $\begin{array}{l}0.04(1 / \\
25)\end{array}$ & $\begin{array}{l}0.00(0 / \\
25)\end{array}$ & $\begin{array}{l}0.02(1 / \\
50)\end{array}$ & $\begin{array}{l}0.00(0 / \\
17)\end{array}$ & $\begin{array}{l}0.00(0 / \\
17)\end{array}$ & $\begin{array}{l}0.00(0 / \\
17)\end{array}$ & $\begin{array}{l}0.00(0 / \\
25)\end{array}$ & $\begin{array}{l}0.00 \\
(0 / 4)\end{array}$ & $\begin{array}{l}0.00(0 / \\
29)\end{array}$ & $\begin{array}{l}0.00(0 / \\
25)\end{array}$ & $\begin{array}{l}0.00(0 / \\
25)\end{array}$ & $\begin{array}{l}0.00(0 / \\
50)\end{array}$ \\
\hline & $\frac{\mathrm{P} / \mathrm{P}}{+}+\underline{\mathrm{F} / \mathrm{F}} \underline{\mathrm{G}} \underline{\mathrm{G}}+\mathrm{T} / \mathrm{T}$ & $\begin{array}{l}0.32(8 / \\
25)\end{array}$ & $\begin{array}{l}0.04(1 / \\
25)\end{array}$ & $\begin{array}{l}0.18(9 / \\
50)\end{array}$ & $\begin{array}{l}0.06(1 / \\
17)\end{array}$ & $\begin{array}{l}0.06(1 / \\
17)\end{array}$ & $\begin{array}{l}0.06(2 / \\
34)\end{array}$ & $\begin{array}{l}0.00(0 / \\
25)\end{array}$ & $\begin{array}{l}0.00 \\
(0 / 4)\end{array}$ & $\begin{array}{l}0.00(0 / \\
29)\end{array}$ & $\begin{array}{l}0.00(0 / \\
25)\end{array}$ & $\begin{array}{l}0.00(0 / \\
25)\end{array}$ & $\begin{array}{l}0.00(0 / \\
50)\end{array}$ \\
\hline \multirow[t]{5}{*}{$\underline{\mathrm{P}-\mathrm{G}}-\mathrm{T}-\underline{\mathrm{C}}$} & $\begin{array}{l}S / P+V / \underline{G}+T / T \\
+\bar{F} / \underline{C}\end{array}$ & $\begin{array}{l}0.12(3 / \\
25)\end{array}$ & $\begin{array}{l}0.00(0 / \\
25)\end{array}$ & $\begin{array}{l}0.06(3 / \\
50)\end{array}$ & $\begin{array}{l}0.24(4 / \\
17)\end{array}$ & $\begin{array}{l}0.06(1 / \\
17)\end{array}$ & $\begin{array}{l}0.15(5 / \\
34)\end{array}$ & $\begin{array}{l}0.12(3 / \\
25)\end{array}$ & $\begin{array}{l}0.00 \\
(0 / 4)\end{array}$ & $\begin{array}{l}0.10(3 / \\
29)\end{array}$ & $\begin{array}{l}0.00(0 / \\
25)\end{array}$ & $\begin{array}{l}0.00(0 / \\
25)\end{array}$ & $\begin{array}{l}0.00(0 / \\
50)\end{array}$ \\
\hline & $\begin{array}{l}\mathrm{S} / \mathrm{P}+\mathrm{G} / \mathrm{G}+\mathrm{T} / \mathrm{T} \\
+\overline{\mathrm{F}} / \underline{\mathrm{C}}\end{array}$ & $\begin{array}{l}0.00(0 / \\
25)\end{array}$ & $\begin{array}{l}0.04(1 / \\
25)\end{array}$ & $\begin{array}{l}0.02(1 / \\
50)\end{array}$ & $\begin{array}{l}0.06(1 / \\
17)\end{array}$ & $\begin{array}{l}0.00(0 / \\
17)\end{array}$ & $\begin{array}{l}0.03(1 / \\
34)\end{array}$ & $\begin{array}{l}0.00(0 / \\
25)\end{array}$ & $\begin{array}{l}0.00 \\
(0 / 4)\end{array}$ & $\begin{array}{l}0.00(0 / \\
29)\end{array}$ & $\begin{array}{l}0.00(0 / \\
25)\end{array}$ & $\begin{array}{l}0.00(0 / \\
25)\end{array}$ & $\begin{array}{l}0.00(0 / \\
50)\end{array}$ \\
\hline & $\begin{array}{l}\underline{P} / P+V / \underline{G}+T / T \\
+\underline{C} / \underline{C}\end{array}$ & $\begin{array}{l}0.04(1 / \\
25)\end{array}$ & $\begin{array}{l}0.00(0 / \\
25)\end{array}$ & $\begin{array}{l}0.02(1 / \\
50)\end{array}$ & $\begin{array}{l}0.06(1 / \\
17)\end{array}$ & $\begin{array}{l}0.00(0 / \\
17)\end{array}$ & $\begin{array}{l}0.03(1 / \\
34)\end{array}$ & $\begin{array}{l}0.00(0 / \\
25)\end{array}$ & $\begin{array}{l}0.00 \\
(0 / 4)\end{array}$ & $\begin{array}{l}0.00(0 / \\
29)\end{array}$ & $\begin{array}{l}0.00(0 / \\
25)\end{array}$ & $\begin{array}{l}0.00(0 / \\
25)\end{array}$ & $\begin{array}{l}0.00(0 / \\
50)\end{array}$ \\
\hline & $\begin{array}{l}\underline{P} / P+G / G+T / T \\
+\bar{F} / \underline{C}\end{array}$ & $\begin{array}{l}0.12(3 / \\
25)\end{array}$ & $\begin{array}{l}0.00(0 / \\
25)\end{array}$ & $\begin{array}{l}0.06(3 / \\
50)\end{array}$ & $\begin{array}{l}0.06(1 / \\
17)\end{array}$ & $\begin{array}{l}0.06(1 / \\
17)\end{array}$ & $\begin{array}{l}0.06(2 / \\
34)\end{array}$ & $\begin{array}{l}0.00(0 / \\
25)\end{array}$ & $\begin{array}{l}0.00 \\
(0 / 4)\end{array}$ & $\begin{array}{l}0.00(0 / \\
29)\end{array}$ & $\begin{array}{l}0.00(0 / \\
25)\end{array}$ & $\begin{array}{l}0.00(0 / \\
25)\end{array}$ & $\begin{array}{l}0.00(0 / \\
50)\end{array}$ \\
\hline & $\frac{\mathrm{P} / \mathrm{P}}{+\underline{\mathrm{C}} / \underline{C}}+\underline{\mathrm{G}} / \underline{\mathrm{G}}+\mathrm{T} / \mathrm{T}$ & $\begin{array}{l}0.00(0 / \\
25)\end{array}$ & $\begin{array}{l}0.00(0 / \\
25)\end{array}$ & $\begin{array}{l}0.00(0 / \\
50)\end{array}$ & $\begin{array}{l}0.06(1 / \\
17)\end{array}$ & $\begin{array}{l}0.00(0 / \\
17)\end{array}$ & $\begin{array}{l}0.03(1 / \\
34)\end{array}$ & $\begin{array}{l}0.04(1 / \\
25)\end{array}$ & $\begin{array}{l}0.00 \\
(0 / 4)\end{array}$ & $\begin{array}{l}0.03(1 / \\
29)\end{array}$ & $\begin{array}{l}0.00(0 / \\
25)\end{array}$ & $\begin{array}{l}0.00(0 / \\
25)\end{array}$ & $\begin{array}{l}0.00(0 / \\
50)\end{array}$ \\
\hline
\end{tabular}

The sites of the $k d r$ mutations are underlined 
Table 3 Associations between the S-V-T-C haplotype and deltamethrin resistance among Ae. aegypti larvae collected from four populations

\begin{tabular}{|c|c|c|c|c|c|c|c|c|c|}
\hline \multirow[t]{3}{*}{ Locality } & \multirow{3}{*}{$\begin{array}{l}\text { No. of } \\
\text { samples } \\
\text { analyzed, } \\
\text { alive/ } \\
\text { dead }\end{array}$} & \multicolumn{3}{|l|}{ Alive } & \multicolumn{3}{|l|}{ Dead } & \multirow{3}{*}{$\begin{array}{l}\text { Odds ratio }(95 \% \\
\text { Cl) }\end{array}$} & \multirow{3}{*}{$\begin{array}{l}\text { Fisher's } \\
\text { exact } \\
\text { test ( } p \\
\text { value) }\end{array}$} \\
\hline & & \multicolumn{2}{|l|}{ No. of mosquitoes } & \multirow{2}{*}{$\begin{array}{l}\text { Freq. of S- } \\
\text { V-T- } \underline{C}\end{array}$} & \multicolumn{2}{|l|}{ No. of mosquitoes } & \multirow{2}{*}{$\begin{array}{l}\text { Freq. of S- } \\
\text { V-T-C }\end{array}$} & & \\
\hline & & S-V-T-F and P-G-T-F & S-V-T-C & & S-V-T-F and P-G-T-F & S-V-T-C & & & \\
\hline Xaythany & $18 / 23$ & 9 & 9 & $0.50(9 / 18)$ & 2 & 21 & $0.91(21 / 23)$ & $0.10(0.2$ to 0.56$)$ & 0.0046 \\
\hline Pakkading & $9 / 12$ & 1 & 8 & $0.89(8 / 9)$ & 3 & 9 & $0.75(9 / 12)$ & 2.67 (0.32 to 38.4$)$ & 0.60 \\
\hline Khounkham & $18 / 3$ & 0 & 18 & $1.00(18 / 18)$ & 0 & 3 & $1.00(3 / 3)$ & Not determined & \\
\hline Thakhek & $24 / 21$ & 1 & 23 & $0.96(23 / 24)$ & 2 & 19 & $0.90(19 / 21)$ & 2.42 (0.03 to 3.83 ) & 0.59 \\
\hline Total & $69 / 59$ & 11 & 58 & $0.84(58 / 69)$ & 7 & 52 & $0.88(52 / 59)$ & 0.71 (0.27 to 2.04) & 0.61 \\
\hline
\end{tabular}

The sites of the $k d r$ mutations are underlined

reference strain; therefore, the diagnostic doses used in previous studies were adopted. The results of the bioassays carried out under these conditions were largely consistent with those obtained in previous studies of $A e$. aegypti populations from Lao PDR and other regions of Southeast Asia [17-19]. Specifically, they revealed that all of the Ae. aegypti populations from the three sites in central Lao PDR were resistant to temephos (diagnostic dose $0.0286 \mathrm{mg} / \mathrm{L}$ ), but the insecticide resistance status of the mosquitoes varied among the study sites. Previous studies of populations from Lao PDR and Malaysia have also reported that Ae. aegypti is resistant to temephos, but the levels of resistance varied among the study sites $[17,19]$. A study conducted in Lao PDR showed that the temephos susceptibility status of Ae. aegypti is "moderate", while the resistance ratios obtained for the central and southern populations at the 50\% and 95\% lethal concentrations ( $\mathrm{LC}_{50}$ and $\mathrm{LC}_{95}$, respectively), i.e., the $\mathrm{RR}_{50}$ and $\mathrm{RR}_{95}$ values, were $>3.0$, suggesting that these Ae. aegypti populations are more resistant to temephos [17]. It should be noted that the temephos formulation recommended by the WHO for controlling mosquito larvae in container habitats contains $1 \mathrm{mg} / \mathrm{L}$ of the active ingredient, which is much higher than the diagnostic dose used in this study and the $\mathrm{LC}_{95}$ reported in previous studies performed in Lao PDR [2, 17, 25]. Thus, using temephos as recommended in the WHO guidelines might be effective at controlling Ae. aegypti larvae in Lao PDR.

All of the Ae. aegypti populations from the three sites in central Lao PDR were "susceptible" to Bti. In a previous study conducted in Lao PDR, the insecticide susceptibility of Ae. aegypti larvae collected from Vientiane to $B t i$ was tested. As a result, it was revealed that the $R_{50}$ and $R_{95}$ values for each of the populations were $<1.0$, suggesting that the larvae were susceptible to Bti [26]. This finding supports the results of the current study. The fact that Bti has never been used in Lao PDR for vector-control programs and has a different insecticide mode of action to temephos and pyrethroids, which have been used in Lao PDR, is considered to explain the absence of resistance to Bti in all of the Ae. aegypti populations tested in the current study [26]. In addition, a study involving a field experiment carried out in

Table 4 Associations between the P-G-T-F haplotype and deltamethrin resistance among Ae. aegypti larvae collected from four populations

\begin{tabular}{|c|c|c|c|c|c|c|c|c|c|}
\hline \multirow[t]{3}{*}{ Locality } & \multirow{3}{*}{$\begin{array}{l}\text { No. of } \\
\text { samples } \\
\text { analyzed, } \\
\text { alive/ } \\
\text { dead }\end{array}$} & \multicolumn{3}{|l|}{ Alive } & \multicolumn{3}{|l|}{ Dead } & \multirow{3}{*}{$\begin{array}{l}\text { Odds ratio } \\
(95 \% \mathrm{Cl})\end{array}$} & \multirow{3}{*}{$\begin{array}{l}\text { Fisher's } \\
\text { exact } \\
\text { test ( } p \\
\text { value) }\end{array}$} \\
\hline & & \multicolumn{2}{|l|}{ No. of mosquitoes } & \multirow{2}{*}{$\begin{array}{l}\text { Freq. of } \underline{P}- \\
\text { G-T-F }\end{array}$} & \multicolumn{2}{|l|}{ No. of mosquitoes } & \multirow{2}{*}{$\begin{array}{l}\text { Freq. of } \underline{P}- \\
\text { G-T-F }\end{array}$} & & \\
\hline & & $\begin{array}{l}\text { S-V-T-F, S-V-T-C, and } \\
\text { S-V-I-C }\end{array}$ & $\begin{array}{l}\mathrm{P}-\mathrm{G}- \\
\overline{\mathrm{T}}-\overline{\mathrm{F}}\end{array}$ & & $\begin{array}{l}\text { S-V-T-F, S-V-T-C and } \\
\text { S-V-I-C }\end{array}$ & $\begin{array}{l}\mathrm{P}-\mathrm{G}- \\
\overline{\mathrm{T}}-\overline{\mathrm{F}}\end{array}$ & & & \\
\hline Xaythany & $17 / 24$ & 9 & 8 & $0.47(8 / 17)$ & 23 & 1 & $0.04(1 / 23)$ & $\begin{array}{l}20.4(2.75 \text { to } \\
234.3)\end{array}$ & 0.0017 \\
\hline Pakkading & $9 / 15$ & 8 & 1 & $0.11(1 / 9)$ & 14 & 1 & $0.07(1 / 15)$ & 1.75 (0.8 to 35.32) & $\begin{array}{l}> \\
0.9999\end{array}$ \\
\hline Khounkham & $0 / 0$ & 0 & 0 & $\begin{array}{l}\text { Not } \\
\text { determined }\end{array}$ & 0 & 0 & $\begin{array}{l}\text { Not } \\
\text { determined }\end{array}$ & Not determined & \\
\hline Thakhek & $0 / 0$ & 0 & 0 & $\begin{array}{l}\text { Not } \\
\text { determined }\end{array}$ & 0 & 0 & $\begin{array}{l}\text { Not } \\
\text { determined }\end{array}$ & Not determined & \\
\hline Total & $26 / 39$ & 17 & 9 & $0.35(9 / 26)$ & 37 & 2 & $0.07(5 / 71)$ & $\begin{array}{l}9.79(2.03 \text { to } \\
47.27)\end{array}$ & 0.0047 \\
\hline
\end{tabular}


Table 5 Associations between the $\underline{\text { P-G-T-C }}-\underline{C}$ haplotype and deltamethrin resistance among Ae. aegypti larvae collected from four populations

\begin{tabular}{|c|c|c|c|c|c|c|c|c|c|}
\hline \multirow[t]{3}{*}{ Locality } & \multirow{3}{*}{$\begin{array}{l}\text { No. of } \\
\text { samples } \\
\text { analyzed, } \\
\text { alive/ } \\
\text { dead }\end{array}$} & \multicolumn{3}{|l|}{ Alive } & \multicolumn{3}{|l|}{ Dead } & \multirow{3}{*}{$\begin{array}{l}\text { Odds ratio } \\
(95 \% \mathrm{Cl})\end{array}$} & \multirow{3}{*}{$\begin{array}{l}\text { Fisher's } \\
\text { exact } \\
\text { test ( } p \\
\text { value) }\end{array}$} \\
\hline & & \multicolumn{2}{|l|}{ No. of mosquitoes } & \multirow{2}{*}{$\begin{array}{l}\text { Freq. of } \\
\text { P-G-T-C }\end{array}$} & \multicolumn{2}{|l|}{ No. of mosquitoes } & \multirow{2}{*}{$\begin{array}{l}\text { Freq. } \\
\text { of P-G- } \\
\text { T-C } \underline{-}-\underline{ }\end{array}$} & & \\
\hline & & $\begin{array}{l}\text { S-V-T-F, S-V-T-C, S-V-I-C } \\
\text { and P-G-T-F }\end{array}$ & $\overline{\mathrm{P}-\overline{\mathrm{G}}-}$ & & $\begin{array}{l}\text { S-V-T-F, S-V-T-C, S-V-I-C } \\
\text { and P-G-T-F }\end{array}$ & $\overline{\mathrm{P}-\mathrm{G}-}$ & & & \\
\hline Xaythany & $25 / 25$ & 18 & 7 & $0.28(7 / 25)$ & 24 & 1 & $0.06(1 / 25)$ & 9.33 (1.35 to 108.8$)$ & 0.049 \\
\hline Pakkading & $17 / 17$ & 9 & 8 & $0.47(8 / 17)$ & 15 & 2 & $0.15(2 / 17)$ & 6.67 (1.32 to 34.56$)$ & 0.057 \\
\hline Khounkham & $24 / 4$ & 21 & 4 & $0.16(4 / 25)$ & 4 & 0 & $0.00(0 / 4)$ & Not determined & \\
\hline Thakhek & $25 / 25$ & 25 & 0 & $0.00(0 / 25)$ & 25 & 0 & $0.00(0 / 25)$ & Not determined & \\
\hline Total & $92 / 71$ & 73 & 19 & $0.21(19 / 92)$ & 68 & 3 & $0.04(3 / 71)$ & $5.90(1.79$ to 19.40$)$ & 0.002 \\
\hline
\end{tabular}

The sites of the $k d r$ mutations are underlined

Malaysia reported that the susceptibility of Ae. aegypti larvae to Bti did not vary, even though Bti had been used intensively for 7 months [27]. Studies performed in Singapore, where Bti has been used as a main larvicide for over 10 years, have also reported that larvae collected from the field exhibited no resistance to Bti $[18,27]$. As mentioned above, the use of Bti as a larvicide is considered to be effective in Lao PDR.

Lamaningao et al. [28] conducted a vector-control field trial using SumiLarv²MR (Sumitomo Chemical Co., Ltd.), which contains pyriproxyfen, an insect growth regulator (IGR) with a different mechanism of action to temephos and Bti, between October 2017 and July 2019. Consequently, it was shown that pyriproxyfen-based interventions were effective at controlling the number of Ae. aegypti larvae in the studied village. As mentioned above, using temephos as a larvicide according to the WHO standards is expected to have sufficient insecticidal effects in Lao PDR. On the other hand, the continuous use of temephos might strengthen the insecticide resistance of Ae. aegypti larvae [18, 27]. Therefore, to allow effective and sustainable temephos usage, it is suggested that the bio-insecticide Bti and the IGR pyriproxyfen, which have different mechanisms of action from temephos, and temephos should be used in rotation.

\section{Pyrethroid resistance}

\section{Bioassays and synergist testing}

The bioassay carried out in the present study demonstrated that the Ae. aegypti populations from the three sites exhibited greater resistance to pyrethroids than to temephos. Many studies conducted in Southeast Asia have reported that Ae. aegypti is highly resistant to pyrethroids [13, 29-32]. On the other hand, little was known about the resistance of Ae aegypti in Lao PDR to pyrethroids until a 2019 study by Marcombe et al. [17], which suggested that most of the Ae. aegypti populations in the northern, central, and southern areas of Lao PDR exhibit resistance to pyrethroids. The current study confirmed that Ae. aegypti populations from Lao PDR displayed resistance to pyrethroids.

Furthermore, synergistic tests were conducted to evaluate the activity of insecticide-metabolizing enzymes. As a consequence, it was shown that when $\mathrm{PBO}$ was added to pyrethroids the mortality rates of the Ae. aegypti populations from Khounkham and Thakhek increased significantly, while no significant change was observed in the mortality rate of the population from Xaythany. When EA and TPP were added to pyrethroids, no significant increase in mortality was observed in any of the Ae. aegypti populations. Generally, PBO inhibits the enzyme activity of P450s, while EA and TPP inhibit the enzyme activities of GSTs and COEs [33, 34]. Thus, it is suggested that P450 enzymatic activity might have played a role in the resistance to pyrethroids seen in the Khounkham and Thakhek populations.

In Lao PDR, pyrethroids are commonly used for fogging to control adult mosquitoes rather than as larvicides (Lamaningao, personal communication with Khammouane Provincial Health Department of Lao PDR). It is reported that common mechanism(s) cause insecticide resistance in both larval and adult mosquitoes [35]. Thus, the mechanism responsible for pyrethroid resistance and the resultant larval population phenotypes observed in the current study might have been acquired at the adult stage. However, it should be noted that resistance profiles can also vary between life stages, in contrast to the findings of the study mentioned above [36]. Thus, further adulticide bioassays are required to validate our findings, as was discussed in previous studies $[18,19]$.

\section{Knockdown resistance $(k d r)$ genotyping}

The present study analyzed sodium channel gene mutations, which are related to resistance to pyrethroids in Southeast Asian Ae. aegypti populations. As a result, the V1016G mutation was detected at an allele frequency ranging from 0 to $31 \%$. Thus, the frequency of $1016 \mathrm{G}$ varied among the populations in the present study. It 
has been reported that the frequency of this mutant allele was high in Ae. aegypti populations from Thailand, Indonesia, and Myanmar, while it was not so high in populations from Vietnam and Lao PDR (0 to 36\%) [13, 17, 29-32, 37-39].

Previous studies clarified that the $1534 \mathrm{C}$ mutant is widely distributed, and its frequency is high in Southeast Asian Ae aegypti populations [31, 32, 40]. In a previous study, the frequency of the $1534 \mathrm{C}$ mutant was found to be high in Ae. aegypti populations from various sites in Lao PDR, but not at one southern site, which was consistent with the results of the current study [17].

We identified a new $k d r$ mutation, S989P (with V1016G or V1016G + F1534C), for the first time in Lao PDR. The co-occurrence of V1016G + S989P and the V1016G + F1534C + S989P triple mutation have been reported in previous studies conducted in other Southeast Asian countries [11, 13, 31, 41].

\section{Associations between $k d r$ mutations and resistant phenotypes}

In the current study, the F1534C mutation was detected at high frequencies in the populations from all four sites; however, no significant association was found between the F1534C mutation and deltamethrin resistance. In the bioassays conducted in a previous study, no association between the F1534C mutation and deltamethrin resistance was observed in Ae. aegypti populations from Thailand, which agrees with the results of the present study [32]. Furthermore, neurophysiological experiments, involving Xenopus oocyte expression systems, also supported the idea that the F1534C mutation is not related to resistance to type II pyrethroids, such as deltamethrin $[12,42]$. However, one limitation of the present study and the study conducted in Thailand [32] is that a single concentration of deltamethrin was used to compare the frequencies of F1534C in bioassays of susceptible and resistant mosquitoes from field populations. In fact, Kushwah et al. [43], who used a similar approach to that adopted in the present study, found that the F1534C mutation was associated with deltamethrin resistance in Indian Ae. aegypti. Furthermore, Fan and Scott [44] reported in their study, in which they used a congenic strain of Ae. aegypti possessing the F1534C mutation, that this mutation confers 16 -fold resistance to deltamethrin. Hence, further investigation is required to evaluate the role of the $\mathrm{F} 1534 \mathrm{C}$ mutation in the deltamethrin resistance seen in Ae aegypti in central Lao PDR.

In contrast to the F1534C mutation, the current study suggested that the V1016G mutation in combination with the S989P mutation (the P-G-T-F haplotype) and the S989P+F1534C double mutation (the P-G-T-C haplotype) were linked to deltamethrin resistance in the
Ae. aegypti population from Xaythany. Both haplotypes result in strong resistance to pyrethroids [11, 12, 42]. Hirata et al. [12] reported that the P-G-T-F haplotype reduced sodium channel sensitivity to permethrin and deltamethrin by 100 - and 10-fold, respectively. Furthermore, the P-G-T-C haplotype reduced sodium channel sensitivity to permethrin and deltamethrin by 1100 - and 90 -fold, respectively. This may result in the failure of pyrethroid-based dengue vector control.

\section{Vector control using pyrethroids}

In the current study, a combination of bioassays, synergistic testing, and $k d r$ genotyping suggested that enhanced metabolizing enzyme (P450) activity, instead of mutations in the sodium channel gene, was involved in the resistance to pyrethroids seen in the Ae. aegypti populations collected from Khounkham and Thakhek. In contrast, it was suggested that mutations in the sodium channel gene, rather than enhanced metabolizing enzyme activity, were involved in the resistance to pyrethroids seen in the Ae. aegypti population from Xaythany. In other words, it was demonstrated that the mechanism responsible for insecticide resistance to pyrethroids varied among local Ae. aegypti populations from different sites in Lao PDR.

In the future, to facilitate efficient and effective vector control using pyrethroids, it will be necessary to elucidate the $k d r$ mutations present in the sodium channel genes of local Ae. aegypti populations in Lao PDR by $k d r$ genotyping and to continuously monitor such populations for the occurrence of certain sodium channel gene mutation haplotypes, especially the P-G-T-F and P-G-T$\mathrm{C}$ haplotypes. In addition, it will be necessary to discuss whether it would be appropriate to use synergists, such as PBO, in some areas of Lao PDR. The use of the synergist $\mathrm{PBO}$ in combination with deltamethrin could be a useful Ae. aegypti management strategy in some areas of Lao PDR.

\section{Limitations of the present study}

In this study, four field populations of Ae. aegypti larvae from central Lao PDR were subjected to bioassays, synergist assays, and $k d r$ allele genotyping, which provided valuable data about the prevalence and mechanisms of insecticide resistance in these populations. However, this study was affected by the following inherent weaknesses: (1) a comprehensive evaluation of dengue controlrelated insecticide resistance in Ae. aegypti populations requires more quantitative measures of the strength of resistance; i.e., $\mathrm{RR}_{50}$ and $\mathrm{RR}_{99}$ should be calculated by determining the $\mathrm{LC}_{50}$ and $\mathrm{LC}_{99}$ ratios of the field and reference strains, and (2) this study involved small sample sizes; i.e., only 3 populations for the bioassays and 4 populations for the $k d r$ genotyping; therefore, further 
investigations involving a larger number of populations are required to confirm the findings of this study.

\section{Conclusion}

The current study revealed the status of insecticide resistance and its underlying mechanisms in Ae. aegypti populations from sites in central Lao PDR. Resistance to temephos was observed in the Ae. aegypti populations from three sites at the diagnostic dose $(0.0286 \mathrm{mg} / \mathrm{L})$ used in the present study. However, this dose represents about one thirty-fifth of the dose recommended by the WHO $(1 \mathrm{mg} / \mathrm{L})$ for Ae. aegypti. Therefore, it is suggested that, when used according to the WHO guidelines, temephos is still effective for larval control of $A e$. aegypti. To ensure effective and sustainable vector control is achieved using insecticides in Lao PDR, the rotational use of a mixture of temephos and other insecticides with different mechanisms of action, such as $B t i$, whose effects were confirmed in the current study, and pyriproxyfen, is recommended. In fact, Marombe et al. [17] recommended the use of alternative insecticides with different mechanisms of action when they conducted vector control using insecticides in Lao PDR in 2019, which supports the findings of the present study.

The current study revealed that the mechanisms responsible for resistance to pyrethroids varied among the Ae. aegypti populations at the three examined sites. Statistical analyses showed strong associations between the sodium channel gene $k d r$ mutations and resistant phenotypes seen in the Ae aegypti population from Xaythany. It was also suggested that increased metabolizing enzyme activity was the main mechanism responsible for the enhanced pyrethroid resistance observed in the Khounkham and Thakhek populations, but not the Xaythany population. A wide variety of metabolizing enzymes, such as P450s, COEs, GSTs, and uridine 5'diphospho-glucuronosyltransferase, are involved in insecticide metabolism [45-47]. Therefore, the detailed mechanisms responsible for such processes are still insufficiently understood, which is not the case for the processes affected by mutations in the sodium channel gene. In light of this, it will be necessary to analyze metabolizing enzyme genes in multiple populations from Lao PDR using DNA sequencing and/or RNA sequencing analysis involving high-throughput sequencing technologies.

\section{Abbreviations}

Bti: Bacillus thuringiensis israelensis; kdr: Knockdown resistance;

P450s: Cytochrome P450 monooxygenases; COEs: Carboxylesterases; GSTs: Glutathione S-transferases; Lao PDR: Lao People's Democratic Republic; DMSO: Dimethyl sulfoxide; WHO: World Health Organization; EA: Ethacrynic acid; PBO: Piperonyl butoxide; TPP: Triphenyl phosphate; PCR: Polymerase chain reaction; ANOVA: Analysis of variance; OR: Odds ratio; $95 \% \mathrm{Cl}$ : 95\% confidence interval; $L C_{50} / L C_{95}: 50 \%$ and $95 \%$ lethal concentrations; $R_{50}$ / $\mathrm{RR}_{95}$ : Resistance ratios obtained at the $\mathrm{LC}_{50} / \mathrm{LC}_{95}$; IGR: Insect growth regulator

\section{Supplementary Information}

The online version contains supplementary material available at https://doi. org/10.1186/s41182-021-00321-3.

Additional file 1: Table S1. Resistance status of Ae. aegypti larvae to different insecticides and synergists in Lao PDR. Table S2. Comparison of the resistant allele frequency among Ae. aegypti larvae from four populations. Table S3. Thirteen genotypes and five haplotypes identified in the present study

\section{Acknowledgements}

We would like to thank Ms. Kaoru Miyata, Central Research Laboratory of Kansai Medical University, for her help with the DNA sequencing. We also thank our partners at the Lao PDR Provincial Health Departments of Vientiane, Bolikhamsai, and Khammouane, and the villagers for their help with the sample collection process.

\section{Authors' contributions}

Conceptualization, resources, methodology, investigation, formal analysis, and writing-original draft preparation: TS; funding acquisition, supervision, writing-review, and editing: SK; resources, methodology, investigation, writing-review, and editing: PL; Investigation and formal analysis: YM, AWD, and NM; resources and field work preparation: $\mathrm{SI}$ and OS; resources and supervision: TX; funding acquisition and project administration: TN. All of the authors have read and approved the final version of the manuscript.

\section{Funding}

This research was partially funded by Kansai Medical University.

\section{Availability of data and materials}

The data supporting the conclusions of this article are included within the article and its additional files. The unique DNA haplotype sequences are available from the DNA Data Bank of Japan (DDBJ, accession = LC605641, LC605642, LC605643, LC605644, and LC605645).

\section{Declarations}

Ethics approval and consent to participate

This study was approved by the National Ethics Committee for Health Research, Ministry of Health, Lao PDR (reference no. 072-2017/NECHR).

Consent for publication

Not applicable

\section{Competing interests}

The authors declare that they have no known competing financial interests or personal relationships that could have influenced the work reported in this paper.

\section{Author details}

${ }^{1}$ Department of Hygiene and Public Health, Kansai Medical University, Hirakata, Osaka, Japan. ${ }^{2}$ Regenerative Research Center for Intractable Diseases, Kansai Medical University, Hirakata, Osaka, Japan. ${ }^{3}$ Station of Malariology, Parasitology, and Entomology, Khammouane Provincial Health Department, Thakhek, Khammouane Province, Lao PDR. ${ }^{4}$ Khammouane Provincial Health Department, Thakhek, Khammouane Province, Lao PDR.

Received: 13 January 2021 Accepted: 12 April 2021

Published online: 21 April 2021

\section{References}

1. WHO. Comprehensive Guideline for Prevention and Control of Dengue and Dengue Haemorrhagic Fever. Revised and expanded edition. WHO Regional Office for South-East Asia. 2011.

2. WHO. Dengue guidelines for diagnosis, treatment, prevention and control: new edition. World Health Organization. 2009. 
3. WHO. Managing Regional Public Goods for Health Community-Based Dengue Vector Control. World Health Organization Regional Office for the Western Pacific. 2013.

4. WHO. Pesticides and their application: for the control of vector and pests of public health importance. World Health Organization. 2006.

5. Ranson H, Burhani J, Lumjuan N, Black WC. Insecticide resistance in dengue vectors. TroplKAnet J. 2010;1(1).

6. Davies TG, Field LM, Usherwood PN, Williamson MS. DDT, pyrethrins, pyrethroids and insect sodium channels. IUBMB Life. 2007;59(3):151-62. https://doi.org/10.1080/15216540701352042.

7. Silver KS, Du Y, Nomura Y, Oliveira EE, Salgado VL, Zhorov BS, et al. Voltagegated sodium channels as insecticide targets. Adv In Insect Phys. 2014;46: 389-433. https://doi.org/10.1016/B978-0-12-417010-0.00005-7.

8. Marcombe S, Bobichon J, Somphong B, Phommavan N, Maithaviphet S, Nambanya S, et al. Insecticide resistance status of malaria vectors in Lao PDR. PLoS One. 2017;12(4):e0175984. https://doi.org/10.1371/journal.pone.0175984.

9. Seixas G, Grigoraki L, Weetman D, Vicente JL, Silva AC, Pinto J, et al. Insecticide resistance is mediated by multiple mechanisms in recently introduced Aedes aegypti from Madeira Island (Portugal). PLoS Negl Trop Dis. 2017;11(7):e0005799. https://doi.org/10.1371/journal.pntd.0005799.

10. Goindin D, Delannay C, Gelasse A, Ramdini C, Gaude T, Faucon F, et al. Levels of insecticide resistance to deltamethrin, malathion, and temephos, and associated mechanisms in Aedes aegypti mosquitoes from the Guadeloupe and Saint Martin islands (French West Indies). Infect Dis Poverty. 2017;6(1):38. https://doi.org/10.1186/s40249-017-0254-x.

11. Plernsub S, Saingamsook J, Yanola J, Lumjuan N, Tippawangkosol P, Sukontason $\mathrm{K}$, et al. Additive effect of knockdown resistance mutations, S989P, V1016G and F1534C, in a heterozygous genotype conferring pyrethroid resistance in Aedes aegypti in Thailand. Parasit Vectors. 2016;9(1): 417. https://doi.org/10.1186/s13071-016-1713-0.

12. Hirata K, Komagata O, Itokawa K, Yamamoto A, Tomita T, Kasai S. A single crossing-over event in voltage-sensitive $\mathrm{Na}+$ channel genes may cause critical failure of dengue mosquito control by insecticides. PLOS Negl Trop Dis. 2014;8(8):e3085. https://doi.org/10.1371/journal.pntd.0003085.

13. Wuliandari JR, Lee SF, White VL, Tantowijoyo W, Hoffmann AA, EndersbyHarshman NM. Association between three mutations, F1565C, V1023G and S996P, in the voltage-sensitive sodium channel gene and knockdown resistance in Aedes aegypti from Yogyakarta, Indonesia. Insects. 2015;6(3): 658-85. https://doi.org/10.3390/insects6030658.

14. Phommanivong V, Kanda S, Shimono T, Lamaningao P, Darcy AW, Mishima $\mathrm{N}$, et al. Co-circulation of the dengue with chikungunya virus during the 2013 outbreak in the southern part of Lao PDR. Trop Med Health. 2016; 44(1):24. https://doi.org/10.1186/s41182-016-0020-y.

15. WHO. Global Strategy for dengue prevention and control, 2012-2020. Diseases DoCoNT, editorAugust 2012

16. Lao M, Caro V, Thiberge JM, Bounmany P, Vongpayloth $K$, Buchy $P$, et al. Cocirculation of dengue virus type 3 genotypes in Vientiane capital, Lao PDR. PLoS One. 2014;9(12):e115569. https://doi.org/10.1371/journal.pone.0115569.

17. Marcombe S, Fustec B, Cattel J, Chonephetsarath S, Thammavong P, Phommavanh $\mathrm{N}$, et al. Distribution of insecticide resistance and mechanisms involved in the arbovirus vector Aedes aegypti in Laos and implication for vector control. PLoS Negl Trop Dis. 2019;13(12):e0007852. https://doi.org/10.1371/journal.pntd.0007852.

18. Koou S-Y, Chong C-S, Vythilingam I, Ng L-C, Lee C-Y. Pyrethroid resistance in Aedes aegyptiLarvae (Diptera: Culicidae) from Singapore. J Med Entomol. 2014;51(1):170-81. https://doi.org/10.1603/ME13113.

19. Leong CS, Vythilingam I, Wong ML, Wan Sulaiman WY, Lau YL. Aedes aegypti(Linnaeus) larvae from dengue outbreak areas in Selangor showing resistance to pyrethroids but susceptible to organophosphates. Acta Trop. 2018;185:115-26. https://doi.org/10.1016/j.actatropica.2018.05.008.

20. Rattanarithikul RHR, Harrison BA, Panthusiri P, Coleman RE, Richardson JH. Illustrated keys to the mosquitoes of Thailand. VI. Tribe Aedini. Southeast Asian J Trop Med Public Health. 2010;41:1-225

21. Kawada H, Higa Y, Futami K, Muranami Y, Kawashima E, Osei JH, et al, Discovery of point mutations in the voltage-gated sodium channel from African Aedes aegypti populations: potential phylogenetic reasons for gene introgression. PLoS Negl Trop Dis. 2016;10(6):e0004780. https://doi.org/10.13 71/journal.pntd.0004780.

22. Kumar S, Stecher G, Tamura K. MEGA7: molecular evolutionary genetics analysis version 7.0 for bigger datasets. Mol Biol Evol. 2016;33(7):1870-4. https://doi.org/10.1093/molbev/msw054.
23. Kanda Y. Investigation of the freely available easy-to-use software 'EZR' for medical statistics. Bone Marrow Transplant. 2013;48(3):452-8. https://doi. org/10.1038/bmt.2012.244.

24. WHO. Monitoring and managing insecticide resistance in Aedes mosquito populations: interim guidance for entomologists. World Health Organization. 2016

25. WHO. Temephos in Drinking-water: Use for Vector Control in DrinkingWater Sources and Containers. 2009.

26. Marcombe S, Chonephetsarath S, Thammavong P, Brey PT. Alternative insecticides for larval control of the dengue vector Aedes aegypti in Lao PDR: insecticide resistance and semi-field trial study. Parasit Vectors. 2018; 11(1):616. https://doi.org/10.1186/s13071-018-3187-8.

27. Loke SR, Andy-Tan WA, Benjamin S, Lee HL, Sofian-Azirun M. Susceptibility of field-collected Aedes aegypti (L.) (Diptera: Culicidae) to Bacillus thuringiensis israelensis and temephos. Trop Biomed. 2010;27(3):493-503.

28. Lamaningao P, Kanda S, Shimono T, Inthavongsack S, Xaypangna T, Nishiyama T. Aedes mosquito surveillance and the use of a larvicide for vector control in a rural area of the Lao People's Democratic Republic. Trop Med Health. 2020;48(1):54. https://doi.org/10.1186/s41182-020-00242-7.

29. Amelia-Yap ZH, Chen CD, Sofian-Azirun M, Low VL. Pyrethroid resistance in the dengue vector Aedes aegypti in Southeast Asia: present situation and prospects for management. Parasit Vectors. 2018;11(1):332. https://doi.org/1 0.1186/s13071-018-2899-0.

30. Kawada H, Higa Y, Komagata O, Kasai S, Tomita T, Thi Yen N, et al. Widespread distribution of a newly found point mutation in voltage-gated sodium channel in pyrethroid-resistant Aedes aegypti populations in Vietnam. PLoS Negl Trop Dis. 2009;3(10):e527. https://doi.org/10.1371/journa I.pntd.0000527.

31. Kawada H, Oo SZ, Thaung S, Kawashima E, Maung YN, Thu HM, et al. Cooccurrence of point mutations in the voltage-gated sodium channel of pyrethroid-resistant Aedes aegypti populations in Myanmar. PLoS Negl Trop Dis. 2014;8(7):e3032. https://doi.org/10.1371/journal.pntd.0003032.

32. Stenhouse SA, Plernsub S, Yanola J, Lumjuan N, Dantrakool A, Choochote W, et al. Detection of the V1016G mutation in the voltage-gated sodium channel gene of Aedes aegypti (Diptera: Culicidae) by allele-specific PCR assay, and its distribution and effect on deltamethrin resistance in Thailand. Parasit Vectors. 2013;6(1):253. https://doi.org/10.1186/1756-3305-6-253.

33. Brogdon WG, Chan A. Guidelines for evaluating insecticide resistance in vectors using the CDC bottle bioassay/methods in anopheles research, vol. 343. 2nd ed. CDC Atlanta USA: CDC technical report; 2010.

34. Bharati $M$, Saha D. Multiple insecticide resistance mechanisms in primary dengue vector, Aedes aegypti (Linn.) from dengue endemic districts of subHimalayan West Bengal, India. PLoS One. 2018;13(9):e0203207.

35. Kasai S, Komagata O, Itokawa K, Shono T, Ng LC, Kobayashi M, et al. Mechanisms of pyrethroid resistance in the dengue mosquito vector, Aedes aegypti: target site insensitivity, penetration, and metabolism. PLoS Negl Trop Dis. 2014:8(6):e2948. https://doi.org/10.1371/journal.pntd.0002948.

36. Melissa C, Hardstone CL, Harrington LC, Kasai S, Tomita T, Scott JG. Cytochrome P450 monooxygenase-mediated permethrin resistance confers limited and larval specific cross-resistance in the southern house mosquito, Culex pipiens quinquefasciatus. Pesticide Biochem Physiol. 2007;89(3):17584

37. Du Y, Nomura $Y$, Zhorov BS, Dong K. Sodium channel mutations and pyrethroid resistance in Aedes aegypti. Insects. 2016;7(4).

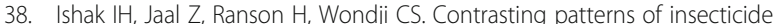
resistance and knockdown resistance $(\mathrm{kdr})$ in the dengue vectors Aedes aegypti and Aedes albopictus from Malaysia. Parasit Vectors. 2015;8(1):181. https://doi.org/10.1186/s13071-015-0797-2.

39. Pang SC, Chiang LP, Tan CH, Vythilingam I, Lam-Phua SG, Ng LC. Low efficacy of delthamethrin-treated net against Singapore Aedes aegypti is associated with kdr-type resistance. Trop Biomed. 2015;32(1):140-50.

40. Yanola J, Somboon P, Walton C, Nachaiwieng W, Somwang P, Prapanthadara LA. High-throughput assays for detection of the F1534C mutation in the voltage-gated sodium channel gene in permethrin-resistant Aedes aegypti and the distribution of this mutation throughout Thailand. Trop Med Int Health. 2011;16(4):501-9. https://doi.org/10.1111/j.1365-3156.2 011.02725.x

41. Srisawat $R$, Komalamisra N, Eshita $Y$, Zheng $M$, Ono K, Itoh TQ et al. Point mutations in domain II of the voltage-gated sodium channel gene in deltamethrin-resistant Aedes aegypti (Diptera: Culicidae). Appl Entomol Zool. 2010;45(2):275-82. https://doi.org/10.1303/aez.2010.275. 
42. Du Y, Nomura Y, Satar G, Hu Z, Nauen R, He SY, et al. Molecular evidence for dual pyrethroid-receptor sites on a mosquito sodium channel. Proc Natl Acad Sci U S A. 2013;110(29):11785-90. https://doi.org/10.1073/pnas.130511 8110.

43. Kushwah RB, Dykes CL, Kapoor N, Adak T, Singh OP. Pyrethroid-resistance and presence of two knockdown resistance (kdr) mutations, F1534C and a novel mutation T1520l, in Indian Aedes aegypti. PLoS Negl Trop Dis. 2015; 9(1):e3332. https://doi.org/10.1371/journal.pntd.0003332.

44. Fan Y, Scott JG. The F1534C voltage-sensitive sodium channel mutation confers 7- to 16-fold resistance to pyrethroid insecticides in Aedes aegypti. Pest Manag Sci. 2020;76(6):2251-9. https://doi.org/10.1002/ps.5763.

45. Faucon F, Dusfour I, Gaude T, Navratil V, Boyer F, Chandre F, et al. Identifying genomic changes associated with insecticide resistance in the dengue mosquito Aedes aegypti by deep targeted sequencing. Genome Res. 2015;25(9):1347-59. https://doi.org/10.1101/gr.189225.115.

46. FdrF J-PD, Chandor-Proust A, Poupardin R, AlB MAR, Navratil V, Reynaud S. Comparative analysis of response to selection with three insecticides in the dengue mosquito Aedes aegypti using mRNA sequencing. BMC Genomics. 2014;15(174):174

47. Faucon F, Gaude T, Dusfour I, Navratil V, Corbel V, Juntarajumnong W, et al. In the hunt for genomic markers of metabolic resistance to pyrethroids in the mosquito Aedes aegypti: An integrated next-generation sequencing approach. PLoS Negl Trop Dis. 2017;11(4):e0005526. https://doi.org/10.1371/ journal.pntd.0005526.

\section{Publisher's Note}

Springer Nature remains neutral with regard to jurisdictional claims in published maps and institutional affiliations.

Ready to submit your research? Choose BMC and benefit from:

- fast, convenient online submission

- thorough peer review by experienced researchers in your field

- rapid publication on acceptance

- support for research data, including large and complex data types

- gold Open Access which fosters wider collaboration and increased citations

- maximum visibility for your research: over $100 \mathrm{M}$ website views per year

At $\mathrm{BMC}$, research is always in progress.

Learn more biomedcentral.com/submissions 